\title{
COMO O PROJETO DE EXTENSÃO PODE CONTRIBUIR NO CAMINHO DA DOCÊNCIA PARA UM ESTUDANTE DE DIREITO: NA PERSPECTIVA DE UMA GRADUANDA EM DIREITO PELA UERN
}

\section{Lorena Maria Medeiros de Oliveira}

Nunca consagrada como uma atividade fácil, a docência no meio acadêmico sempre veio acompanhada de críticas no que tange à metodologia aplicada e didática, essas que vêm tanto dos docentes como dos discentes que acompanham o processo letivo. Ainda assim, é uma atividade essencial para a coletividade, não apenas porque constrói bases subjetivas para o aprimoramento técnico, teórico e moral do estudante; mas também atua em contribuição direta para a sociedade. Neste escopo, o objetivo desta resenha é explanar como os próprios estudantes podem ter suas vidas influenciadas por intermédio de um elemento intrínseco para a docência: a extensão. Nesse caso, focar-se-á no projeto "Socializando o Direito", ofertado pela Universidade do Estado do Rio Grande do Norte (UERN) para os alunos da Faculdade de Direito (FAD).

O projeto de extensão "Socializando o Direito" teve sua fundação em 2018 (estando ativo até o presente momento) por concepção de seu idealizador, o professor Francisco Marcos de Araújo. Atualmente, é encabeçado pela coordenadora Dra. Denise dos Santos Vasconcelos Silva e, como vice coordenador, o professor Me. Emanuel de Melo Ferreira, auxiliados também pela professora Me. Fernanda Abreu de Oliveira. Foi concebido com o intuito de oportunizar aos discentes o contato com a vivencia jurídica e a docência do Direito fora das paredes da universidade. Suas principais ações envolvem a idealização de palestras de cunho diversificado, que são apresentadas, especialmente, em colégios da rede pública.

O projeto conta com três linhas de extensão. A primeira visa trabalhar com Direitos Transindividuais e Educação para a Democracia, e atua na produção e ministração de palestras sobre meio ambiente, Democracia, responsabilidade e participação cidadã. A segunda linha abarca Direitos políticos, e atua em temas como o autoritarismo judicial e o uso político do Direito. Por fim, a terceira linha estuda os Direitos Humanos das mulheres e a educação jurídica sob a perspectiva de gênero, pesquisando sobre assuntos como a violência contra a mulher e seus condicionantes, bem como a participação feminina na política e no Poder Judiciário.

A ministração das palestras acontece, majoritariamente, em colégios públicos. A escolha dos espaços dá-se a partir de critérios como, por exemplo, a natureza da instituição (se é pública ou privada). O direcionamento teórico é adequado de acordo com o tema da palestra, desse modo temas de maior complexidade podem ser aplicados para alunos que possam questionar e observar as minúcias das questões trazidas, o que proporciona um debate entre os palestrantes (que são discentes participantes do projeto) e o público.

${ }^{1}$ Graduanda em Direito pela Universidade do Estado do Rio Grande do Norte. Membro do Projeto de Extensão "Socializando o Direito" e do Centro Acadêmico Rui Barbosa (CARB) da Faculdade de Direito - FAD. 
Esses debates são bastante importantes, visto que não apenas atestam o envolvimento direto dos estudantes, como também incitam sua curiosidade sobre a matéria, além de agregar aos saberes dos próprios palestrantes. Esse método é essencial, pois fundamenta a base para um discurso que ultrapassa as paredes das escolas, fomentando uma ressignificação de símbolos, ações e preceitos por parte do aluno na coletividade em que está inserido.

A experiência proveniente desses debates com o público (que, muitas vezes, trabalham com cenários plausíveis da cotidianidade) expressa a importância da prática cuidadosa se deve ter o docente ao comandar uma turma. Isso se dá, pois, enquanto na posição de palestrantes, os discentes do projeto de extensão conseguem perceber a necessidade de cultivar uma postura profissional e uma desenvoltura ao repassar o aprendido. É compreendido na prática, portanto, que a bagagem de experiência não é suficiente: deve-se trabalhar a forma de apresentá-la.

Neste ponto, é importante destacar o cuidado sempre reforçado com o estudo prévio da matéria e a assimilação dos conhecimentos sobre mediação didática - isto é, o tipo de operação que posiciona o professor como o mediador da interação sujeito e objeto. Esse professor tem a função de tornar o objeto desejável ao sujeito (o chamado "desejo de saber"), o que fundamenta a mediação didática. Dessa forma, a função do docente não é apenas transmitir informações e sim instigar o aluno a se apropriar do conhecimento e usá-lo para diversos processos.

Mas como pode o estudante de Direito, que, muitas vezes, não tem um acompanhamento que lhe apresente tais requisitos, chegar a obter esse saber ou mesmo um pouco de experiência nesse âmbito, uma vez que o bacharelado não prepara para a docência, como faz a licenciatura?

Nestes casos, o único meio de acesso é a prática, que pode se dar por meio de estágios, apresentações costumeiras e, em cunho mais eficaz, o envolvimento em um projeto de extensão que oferta a oportunidade aos discentes de se relacionar mais intimamente com a docência.

É notória, então, a importância dos projetos de extensão na vida acadêmica, pois estes abrem portas para novas oportunidades atuação. Porém, não estão sozinhos nessa questão: são acompanhados pela eficácia indubitável da pesquisa. Consagrando-se como essencial para uma formação docente ampla e multifacetada, a pesquisa contribui com a extensão e vice-versa, pois não se pode praticar sobre o que se desconhece, e não se pode estudar o que não é praticável.

Destarte, não se pode deixar de mencionar a importância do empenho que deve ter a Universidade e os docentes em prover essas oportunidades aos discentes por meio dos projetos, posto que um necessita do outro na construção de um ambiente acadêmico mais atuante e plural, em que os alunos tenham voz e vez para expressar suas opiniões e conhecimentos adquiridos durante o ensino, sem que haja uma centralização dos poderes nas mãos de um só corpo docente.

Reforça-se, ainda, que o projeto de extensão muito pode contribuir para a construção da vida universitária estudantil. A elaboração e ministração de uma palestra, o ensinamento da prática, o desafio que 
têm os discentes ao adequarem para diversas faixas etárias seus temas de extrema relevância, todas essas atividades agregam à graduação de forma orgânica. Além disso, despertar nos ouvintes o interesse pelo direito, bem como o conhecimento de mundo necessário para se viver em uma sociedade mutável também auxilia no crescimento pessoal do público.

Para os discentes que almejam tornar-se docentes no futuro, a extensão é intrínseca, pois, cada vez mais desafiadora, os convidam a encarar seus medos e suas ansiedades, trabalhar em sua postura e sua voz, melhorar sua didática, sua mediação e seu conhecimento da realidade de vida do público. Ela também ajuda a solidificar o interesse em tal profissão - que tanto chama para si diversas responsabilidades -, que é pouco valorizada, deixando, inclusive, o incentivo para outros discentes transformarem outras vidas por meio da docência.

Registra-se, por oportuno, a singular importância do projeto de extensão (em especial do "Socializando o Direito", da UERN) para o crescimento do discente enquanto almejante letivo, porquanto o conhecimento que extrai é fundamental para o amadurecimento profissional, ante a multiplicidade de experiências que são desenvolvidas e, por consequência, absorvidas.

Destaca-se, por fim, que o projeto de extensão "Socializando o Direito" se mostra como uma rica oportunidade para aprofundar os lações de interação entre os docentes e discentes que estão à frente do projeto - um espaço de troca de experiências e aprendizado, com a valorização do trabalho em equipe, o que é essencial para a construção de uma sociedade plural.

\section{REFERÊNCIAS BIBLIOGRÁFICAS}

D'ÁVILA, Cristina Maria. Decifra-me ou te devorarei: o que pode o professor frente ao livro didático? Prefácio de José Carlos Libâneo, 2ed. Salvador: EDUNEB; EDUFBA, 2013. 